\title{
EFEK HIPOGYKEMIA PEMBERIAN EKSTRAK DAUN JOHAR PADA TIKUS (MUS MUSCULUS) YANG DI INDUKSI DENGAN STREPTOZOTOSIN
}

\author{
Hypoglycemic Effect of Johar's Leaf Extract (Cassia siamea Lamk) In Mice (Mus \\ musculus) That Induced by Streptozotosin
}

Dyah Ika Krisnawati

\begin{abstract}
This thesis examines whether there johar leaf extracts hypoglycemic effect in mice made diabetic by induction streptozotosin. This type of research in this thesis is the experimental research, the design used was Pretest and Posttest Control Group Design. By using Federer formula, the number of samples are 24 mice were divided into 4 treatment groups: the $1^{\text {st }}$ group as the control group was given CMC-na $0.5 \%$, the $2^{\text {nd }}$ group was given a dose of $0.5 \mathrm{~g} / \mathrm{kgBW}$ of johar extract $/ \mathrm{kg}$, the $3^{\text {rd }}$ Group was given johar extract $1 \mathrm{~g} / \mathrm{kgBW}$, and the $4^{\text {th }}$ group were given a dose of $2 \mathrm{~g}$ johar extract $/ \mathrm{kgBW}$. Examination of the blood glucose test was done using NESCO TEST. The results of post-treatment blood sugar outline obtained an increase in blood sugar in group 1 and group 2, while in group 3 and group 4 showed a decrease in blood sugar levels. Normality test results obtained p values> 0.05 is 1165 , so it could be said to be normally distributed data. Homogeneity test results obtained p values $>0.05$ is 0.106 , so the data can be said to be homogeneous. Observations of blood glucose levels in all groups get $p$ value $>0.05$ that is 0.708 so it can be said from the time of reduction in blood sugar levels are not significant, while the value obtained from the group of $p<0.05$ is 0.020 , Its can be significant. The conclusion of this study of johar leaf extract is not so useful when given to the type of insulin-dependent diabetes mellitus.
\end{abstract}

Keywords: johar leaf extract, mice, blood sugar levels, and streptozotosin

\section{PENDAHULUAN}

Salah satu jenis penyakit yang saat ini sedang menjadi masalah yang cukup rumit di dunia kesehatan dan merupakan gangguan endokrin yang paling banyak dijumpai adalah diabetes mellitus (DM) (Sheerwood, 2001). Salah satu gambaran DM yang paling menonjol adalah peningkatan kadar glukosa darah atau hiperglikemia yang disebabkan oleh efek insulin yang tidak adekuat. Insulin adalah hormon yang dapat menurunkan kadar glukosa darah, (Sheerwood, 2001).

Pada sebagian besar kasus DM disebabkan oleh berkurangnya sekresi insulin oleh sel-sel beta Langerhans. Faktor herediter biasanya memainkan peranan besar dalam menentukan pada siapa DM akan berkembang dan pada siapa DM tidak akan berkembang (Guyton, 2006). DM dapat menimbulkan berbagai komplikasi kronik pada mata, ginjal, saraf dan pembuluh darah serta lesi pada membran basalis dalam pemeriksaan dengan mikroskop elektron (Mansjoer, 2007).

Saat ini penanggulangan kejadian hiperglikemi dapat dilakukan baik secara konvensional, tradisional maupun komplementer. Seiring dengan semakin kompleksnya masalah yang terjadi seputar DM dan beberapa keunggulan penggunaan obat herbal, dalam hal ini adalah terapi tradisional. Masyarakat masa kini mulai melirik penggunaan obat herbal sebagai sarana penanggulangan terhadap melonjaknya kadar glukosa darah, dimana salah satu obat herbal yang bisa 
menanggulangi hiperglikemi adalah daun johar. Johar mengandung flavonoid, suatu senyawa yang disinyalir dapat menurunkan kadar gula darah (Dahroji, 2009). Flavonoid merupakan senyawa kimia yang bekerja sebagai antioksidan, memiliki hubungan sinergis dengan vitamin $\mathrm{C}$ (meningkatkan efektivitas vitamin C), antiinflamasi, menghambat pertumbuhan tumor, dan mencegah keropos tulang (IPB,2012). Flavonoid yang terkandung dalam daun johar adalah jenis Quercetin, disamping terdapat juga zat aktif lainnya yaitu Alkaloid, Tanin dan Barokol.

Pada akhir era 1970 an, Soewandi, berhasil memperkaya manfaat tanaman herbal daun johar dengan secara ilmiah membuktikan rebusan daun johar bisa menyembuhkan penyakit DM atau kencing manis. Purno (1991) telah melakukan penelitian efek hipoglikemik air rebusan daun Johar, pada tikus putih jantan, dibandingkan dengan tolbutamid. Dari hasil penelitian tersebut, ternyata air rebusan daun johar dosis 2,5, 5,0, dan 10,0 $\mathrm{g} / \mathrm{KgBB}$ mampu menurunkan kadar glukosa darah terhadap kontrol negatif, pada kelompok tikus normal yang diberi beban glukosa. Pada kelompok tikus normal yang tidak diberi beban glukosa, air rebusan daun Johar dosis 10,0 g/KgBB mampu menurunkan kadar glukosa darah sebesar $15.06 \%$ terhadap kontrol negatif (iptek.net,2005).

Streptozotosin (STZ) merupakan bahan diabetogenik yang banyak digunakan dalam penelitian selain aloksan. STZ merupakan agen antimicrobial yang juga digunakan sebagai agen alkilasi kemoterapi. Pada tahun 1963, Rakieten et al. menyebutkan bahwa STZ bersifat diabetigenik yang ditandai dengan sindroma insulinopenia yang disebut dengan diabetes STZ, yang disebabkan oleh nekrose spesifik sel beta pancreas dan STZ merupakan bahan kimia pilihan untuk induksi hewan coba pada penelitian tentang DM dengan kerusakan pankreas (Lenzen, 2007).

\section{METODE}

\section{Rancangan penelitian}

Adapun rancangan penelitian yang digunakan dalam penelitian ini adalah pretest and posttest control group design.

\section{Sampel}

Besaran sampel ditentukan dengan rumus Federer (Hanafiah, 1997 ) sebagai berikut :

$(\mathrm{t}-1)(\mathrm{r}-1) \geq 15$

$(4-1)(\mathrm{r}-1) \geq 15$

$\mathrm{r} \geq 6$

Ket :

$\mathrm{t}$ : Jumlah kelompok

$\mathrm{r}$ : jumlah replikasi

Jumlah replikasi per kelompok adalah 6 , sehingga jumlah hewan coba 6 ekor x 4 kelompok $=24$ ekor.

\section{Cara pembuatan sediaan dan dosis daun johar}

Daun johar dikeringkan dengan diangin-anginkan. Simplisia kering digiling halus hingga diperoleh serbuk. Dilakukan pembuatan ekstrak dengan cara maserasi dengan alkohol sebagai pelarut. Ekstrak yang diperoleh dikeringkan dengan waterbath hingga diperoleh ekstrak kental

Berdasarkan penelitian Purno (1991) air rebusan daun Johar dosis 2,5, 5,0, dan $10,0 \mathrm{~g} / \mathrm{kg} \mathrm{BB}$ mampu menurunkan kadar glukosa darah terhadap kontrol negatif. Pada kelompok tikus normal yang tidak diberi beban glukosa, air rebusan daun Johar dosis 10,0 g / kg BB mampu menurunkan kadar glukosa darah sebesar $15,06 \%$ terhadap kontrol negatif.

Pada ekstraksi simplisia kering akan menghasilkan ekstrak sebanyak $10 \%$ dari berat simplisia kering. Maka pada penelitian ini akan dilakukan penelitian dengan ekstrak 0,5, 1 dan 2 gram/Kg BB dengan volume pemberian $1 \mathrm{ml} / 100$ gram BB.

Cara membuat sediaan ekstrak daun johar yang dibutuhkan :

Diekstrak 0,$5 ; 1 ; 2$ gram/KgBB 
Rencana pemberian sediaan $1 \mathrm{ml} / 100$ gram BB

$$
\begin{aligned}
& \frac{0,5 \text { gram }}{\mathrm{KgBB}} ; \frac{1 \text { gram }}{\mathrm{KgBB}} ; \frac{2 \text { gram }}{\mathrm{KgBB}} \\
& \frac{0,5 \text { gram }}{1000 \mathrm{gBB}} ; \frac{1 \text { gram }}{1000 \mathrm{gBB}} ; \frac{2 \text { gram }}{1000 \mathrm{gBB}} \\
& \frac{0,05 \text { gram }}{100 \text { gram }} \frac{0,1 \text { gram }}{100 \text { gram }} ; \frac{0,2 \text { gram }}{100 \text { gram }} \\
& \text { Jika } 100 \text { gram }=1 \mathrm{ml}
\end{aligned}
$$

1. Membuat sediaan 2 gram $/ \mathrm{KgBB}$ ( sebagai larutan induk )

$$
\frac{0,2 \text { gram }}{\mathrm{ml}}=\frac{20 \text { gram }}{100 \mathrm{ml}}
$$

Cara membuat sediaan: timbang 20 gram ekstrak daun johar tambahkan larutan CMC-Na 0,5\% sampai mencapai volume $100 \mathrm{ml}$

2. Membuat sediaan $1 \mathrm{~g} / \mathrm{KgBB}$

Sediaan induk diambil $50 \mathrm{ml}$ ditambahkan CMC-Na 0,5 \% sampai dengan $100 \mathrm{ml}$.

3. Membuat Sediaan $0,5 \mathrm{~g} / \mathrm{KgBB}$

Sediaan dosis $1 \mathrm{~g} / \mathrm{KgBB}$ diambil 50 $\mathrm{ml}$ ditambahkan CMC-Na 0,5 \% sampai dengan $100 \mathrm{ml}$.

\section{Pembuatan sediaan dan penghitungan dosis STZ}

Diperkirakan berat badan mencit 25 gram dengan dosis STZ $150 \mathrm{mg} / \mathrm{KgBB}$, keperluan STZ per mencit :

$\frac{150}{1000} \times 25$ gram $=3,75 \mathrm{mg} /$ mencit

Kebutuhan STZ untuk 30 mencit $=3,75 \mathrm{x}$ $28=112,5 \mathrm{mg}$

Kebutuhan dapar sitrat 4,5\% adalah 1,5 $\mathrm{ml}$ per 10 tikus $=0,15 \mathrm{ml} / \mathrm{mencit}$

Jadi pembuatan larutannya adalah 112,5 mg STZ dilarutkan ke dalam 4,5 ml Dapar sitrat $4,5 \%$.

Kebutuhan larutan STZ masing - masing mencit didasarkan pada berat badan masing - masing mencit.

\section{Intervensi}

Mencit sejumlah 24 ekor diukur kadar glukosa darah (pada ekor) dengan cara dibersihkan dengan kapas alkohol, kemudian digunting ujung ekor, darah yang keluar diteteskan pada strip Nesco meter, kemudian hasilnya akan terbaca pada alat Nesco meter, ditunggu selama 30 detik, dan memberikan hasil analisa berupa kadar glukosa darah tikus dalam $\mathrm{mg} / \mathrm{dl}$.

Mencit kemudian diinjeksi dengan STZ $\quad 150 \quad \mathrm{mg} / \mathrm{Kg} \quad \mathrm{BB}$ secara intraperitoneal. Jika induksi dilakukan siang, malam harinya mencit diberi minum Dekstrosa $10 \%$ untuk menghindari hipoglikemi. Setelah 48 jam, mencit dipuasakan selama 10 jam, diukur kadar glukosa darah sebelum perlakuan, dilakukan randomisasi 24 ekor mencit yang dibagi menjadi 4 kelompok, yaitu kelompok 1-4 masing-masing sebanyak 6 ekor mencit.

K1 s/d K5 adalah kelompok pengamatan, dibagi menjadi pengamatan sebelum perlakuan (01 s/d 04) dan pengamatan setelah perlakuan (O5 s/d O8).

P0 s/d P3 adalah :

$\mathrm{P} 0=$ kelompok kontrol hanya diberi CMC $\mathrm{Na} 0,5 \%$

$\mathrm{P} 1$ = perlakuan yang diberi ekstrak daun johar dosis 0,5 g/ KgBB

$\mathrm{P} 2$ = perlakuan yang diberi ekstrak daun johar dosis $1 \mathrm{~g} / \mathrm{KgBB}$

$\mathrm{P} 3$ = perlakuan yang diberi ekstrak daun johar dosis $2 \mathrm{~g} / \mathrm{KgBB}$

(P1, P2, P3 masing-masing diberikan dosis peroral $1 \mathrm{ml} / 100 \mathrm{gBB}$ ),

Setelah diberi perlakuan tiap kelompok diambil darahnya pada jam ke1, jam ke-2, jam ke-3 dan tentukan kadar glukosa darahnya dengan Nesco meter. Kemudian data hasil pengamatan sebelum dan sesudah perlakuan dianalisis.

\section{Analisis Data}

Data hasil penelitian dianalisis dengan menggunakan program SPSS for Windows XP yang meliputi analisis 
statistik sebagai berikut (Zainuddin, 2010)

1. Uji statistik deskriptif untuk menggambarkan tentang ringkasan data-data seperti rerata, standar deviasi, varian, modus dan lain-lain.

2. Uji homogenitas data awal untuk mengetahui apakah data awal homogen atau tidak, digunakan untuk mengetahui apakah beberapa varian populasi adalah sama atau tidak, dilakukan sebagai persyaratan uji anova.

3. Uji normalitas untuk mengetahui apakah populasi data berdistribusi normal atau tidak

4. Uji Anova / One Way Anova untuk mengetahui ada atau tidaknya perbedaan rata-rata untuk lebih dari dua kelompok sampel.

HASIL

Pemberian ekstrak daun johar dengan dosis 0,5 dan $1 \mathrm{~g} / \mathrm{KgBB}$ tidak menurunkan kadar glukosa darah, tetapi pada dosis 2 $\mathrm{g} / \mathrm{KgBB}$ menurunkan kadar glukosa darah mencit (Mus musculus) yang dijadikan diabetes mellitus dengan induksi streptozotosin.

Tidak terdapat korelasi antara peningkatan dosis ekstrak daun johar dengan efek penurunan glukosa darah mencit (Mus musculus) yang dijadikan diabetes mellitus dengan induksi streptozotosin.

\section{DAFTAR PUSTAKA}

Abdelmoaty, MA, Ibrahim MA, Ahmed NS and Abdelaziz MA 2010,' Confirmatory studies on the antioxidant and antidiabetic effect of quercetin in rats.' Indian Journal of Clinical Biochemestry; 25 (2) 188192

Adewole SO, Martins EA C and Ojewole AO 2007,' Protective effect of quercetin on the morphology of pancreatic beta-cells of streptozotocin-treated diabetic rats.' Afr. J. Trad. CAM 4 (1): 64-74

Aguirre L, Arias N, Macarulla M T, Gracia A and Portillo M 2011,' Beneficial effects of quercetin on obesity and diabetes.' The Open Nutraceuticals Journal, 4, 189-198

Ayyanar, M and Babu, PS 2012,' Syzygium cumini (L.) Skeels: A review of its phytochemical constituents and traditional uses.' Asian Pacific Journal of Tropical Biomedicine 240-246.

Brunner \&Suddart, 2001, Buku ajar keperawatan medikal bedah, Vol. 2, Edisi 8. EGC, Jakarta.

Chatsri D, et all, 2005, 'Barakol extracted from cassia siamea stimulates chloride secretion in rat colon.' The Journal of Pharmacology and Experimental Therapeutics, Mahidol University, Bangkok, Thailand, vol. 314, no. 2, PP. 732 - 737.

Colugo 2006, 'Musmusculus, the house mouse.' Oragon USA

Evelyn C.P, 2002, Anatomi dan fisiologi untuk paramedis, Gran kkarta.

Ganong, 2008, Buku ajar fisiologi kedokteran, edisi 17, EGC, Jakarta.

Guyton AC and Hall.JE, 2006, Buku ajar fisiologi kedokteran,edisi 11, EGC, Jakarta.

Hanafiah,K.A, 1995, Rancangan percobaan teori dan aplikasi, Raja Grafindo Persada, Jakarta Utara.

Hariadi, 2009, Beternak tikus putih, Pustaka Baru Press, Yogyakarta.

Heinrich,2010, Farmakognosi dan fitoterapi, EGC, Jakarta. 
Heyne K, 1987, Tumbuhan berguna Indonesia, Jilid III, diterjemahkan oleh Badan

Litbang Kehutanan, Departemen Kehutanan, Jakarta.

http://www.iptek.net.id/ind/pd_tanobat/vie w.php?id=295

http://dahroji.wordpress.com/2009/07/14/ diabetes-1/

http://Ipteknet.2008,tanaman obat Indonesia http://www.iptek.net.id.

IPB 2012, 'Tentang johar.' Mei 2012

Irwin et Barneby 2001,' Informasi singkat benih senna siamea (Lamk).' Indonesia Forest Seed Project, No. 11 Maret 2001.

Katzung, 1998,Farmakologi dasar dan klinik, edisi VI, EGC, Jakarta.

Lanzen.S 2008,' The mechanism of aloxan-and streptozotocin-induced diabetes.' Diabetologia Institute of Biochemistry, Hannover Medical School Germany, 51:216-226.

Mansjoer, A 2007, Kapita selekta kedokteran, Media Aeskulapius, Jakarta.

Mark, A 2009, ‘ABC don't ever forget glucose.' British Journal of Hospital Medicine, Vol. 70 No. 4.

Nugroho,AE 2006,' Hewan percobaan diabetes mellitus : patologi dan mekanisme

aksi

diabetogenik.'Biodiversitas

Surakarta, Vol. 7, No.4 pp 378-382.

Peter JF 2001, 'Alkaloid biosynthesis in plants : biochemistry, cell biology, molecular regulation, and metabolic engineering applications.' Depertement of Biological Sciences, University of Calgary, Canada, vol. 52, PP. 29-66.

Price \& Wilson, 2005, Patofisiologi konsep klinis proses - proses penyakit, Vol.2, Edisi 6, EGC, Jakarta.

Rhodes and White, 2002,'Molecular insights into insulin action and secretion.' European Journal of Clinical Investigation; 3-13.

Sherwood, 2001, Fisiologi manusia, dari sel ke sistem, edisi pertama, EGC, Jakarta.

Syaifoellah, 1999, Buku ajar ilmu penyakit dalam, Jilid 1, EGC, Jakarta.

Tanit, P and Wandee, G 2006, 'Barakol contents in fresh and cooked senna siamea leaves.' Departement of Pharmacognosy, Faculty of Pharmacy, Mahidol University, Bangkok, Thailand, vol. 37 No. 2, PP. $388-393$.

Zainuddin, M, 2000, Metodologi penelitian, Surabaya. 